\title{
$\operatorname{PPSM}_{2016}^{6}$
}

ARTICLES $: \because 8$

:

0

Rodrigo Espiúca dos Anjos SIQueIra ${ }^{1}$

University of the West of Santa Catarina

Thaís Janaina Wenczenovicz ${ }^{2}$

State University of Rio Grande do Sul

\section{THE CONSTITUTIONAL PRINCIPLES OF HUMAN DIGNITY, FREEDOM AND EQUALITY AS FUNDAMENTS OF HORIZONTAL EFFICACY OF THE FUNDAMENTAL RIGHTS}

Keywords: Fundamental Rights, Fundaments, Equality, Freedom, Human Dignity

1. Description of the Key CUltural and historical processes THAT MARKED THE CONSTRUCTION OF THE COMMON SENSE OF THE REPRESENTATION OF THE FUNDAMENTAL SOCIAL RIGHTS IN BRAZIL

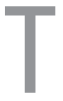
he emergence of a social system in Brazil occurred between 1930 and 1945 , with the change of an agricultural economy to an industrial-urban one, encouraging state intervention to guarantee the rights to health, education, social security, job security, housing and so on. To be noted

\footnotetext{
${ }^{1}$ Attorney at Law. Master in Law by the Univeristy of the West of Santa Catarina (UNOESC). Lecturer at the Anglican Colleges of Erechim and Tapejara-RS, Brazil. espiuca@yahoo.com

${ }^{2}$ Assistant Lecturer at the State University of Rio Grande do Sul (UERGS)/Brazil. t.wencze@terra.com.br
} 
that in this process of construction of Fundamental Rights in Brazil, the social rights had their inclusion in the positive law even before the guarantees of civil and political rights, confirming the strong influence of two sociocultural movements, slavery and colonialism.

From 1946, with the promulgation of the Constitution of 46, as well as through the creation of the Brazilian industry and the major incentive for national industrialization, gained strength grassroots movements, especially the trade union and students. However, in the 1970s and 1980s, with the installation of the military dictatorship, again disempowering the civil and political rights, the social rights were granted as a compensation for the loss of civil and political rights and the excessive control of freedom and ideas from the government.

In the late 1980s, with the end of the military rule and the democratization of the country, the civil and political rights returned to evidence. These rights had special attention with the promulgation of the Constitution of 1988. A number of other social rights were strengthened, for example, social security, health (with the creation of the National Health System) and social assistance (with the advent the Organic Law of Social assistance).

Allied to all this we see as strong influences in the formation of Brazilian conceptual framework of Fundamental Rights, the "colonels", cronyism and despotism, which left popular accommodation heritage and a political bargaining culture where few hold political power through financial strength, obtaining support by haggling and buying votes.

In this context, and in the pursuit of realization of human rights, there is the need to study and widely disseminate the rights and duties of all citizens, in particular the fundamental rights, as these are the most expensive and necessary to all because of their essentiality in ensuring human dignity, which is the same considered as the foundation of those.

\section{THE VeRTiCAL EFFICACY OF THE FUNDAMENTAL RightS}

In relations between the state and individuals, to have the fundamental rights as fundamental in protecting the individual against arbitrariness of government. Without proper guarantee these fundamental rights, the individual is totally vulnerable and likely to suffer from abuses of power, being 
:::: R. E. dos Anjos Siqueira, T. J. Wenczenovicz, The constitutional principles... 49

at the mercy of the state, subject to social abandonment and suffering from a lack of basic resources essential to a dignified life violence. However, this efficiency is not easy to achieve, there are many variables that must be considered, such as the political will of governments and the lack of competent bodies to ensure its implementation.

As a result of the historical construction of human rights, there is the Universal Declaration of Human Rights, adopted on 10 December 1948, the United Nations General Assembly, without, however, practical means to enforce the implementation of the rights contained therein. As can be seen from the jurist Dalmo de Abreu Dallari:

"The big problem, still unsolved, is achieving effectiveness of standards of Rights. Proclaimed as legal, previous standards to the States, they should be applied independently of their inclusion in states' rights by legislative formalization. However, the absence of a body that can impose their effective implementation or to impose sanctions in case of failure, often the very States that signed the Declaration act against their standards, without which nothing can be done" ${ }^{3}$.

Even in the wake of Dallari, the lesson is that the States, in an attempt to realize the rights proclaimed in the Universal Declaration of Human Rights, gradually adopt the practice to include in their chapter constitutions on the rights and guarantees. Brazil adopted this practice, and its Federal Constitution enacted in 1988, by enshrining rights and guarantees, giving this Constitution the nickname "The Citizen Constitution"

Given the difficulty in ensuring the effectiveness of the fundamental rights standards, duly enshrined in law declarations and constitutions of the states, it is necessary a brief examination of the meaning given to the term efficiency in Brazilian constitutional doctrine. As says the teacher and judge Ingo Wolfgang Sarlet, the term effectiveness encompasses a "multiple range of issues subject to questioning and analysis, although this is confined

${ }^{3}$ D. de A. Dallari, Elementos de teoria geral de Estado, Saraiva, São Paulo 2011, [30th ed.], p. 211.

${ }^{4}$ Ibidem. 
to the constitutional right and is, moreover, neuralgic point for the study of the Constitution" 5 .

Says the Brazilian Federal Constitution, in Article 5. § 1. that: "The provisions defining fundamental rights and guarantees are immediately applicable"6.

This is the normative principle that should be deeply analyzed in the search for the meaning of the effectiveness of fundamental rights, since it is the main weapon given to fundamental rights defenders.

In the study of the meaning of effectiveness, we find some similarity between efficiency and effectiveness. In this sense, it is urgent to differentiate the two concepts, efficiency and effectiveness, to get the results that are proposed this test. Again, we find in the lessons of Professor Sarlet the answer to the question made. In this sense, Sarlet gives masterly lesson demonstrating that the Brazilian doctrine, shows a distinction between the concepts of validity and effectiveness, stating that:

"The term is the quality standard that is legally exist (after regular promulgation and publication), making it mandatory compliance in such a way that the term is true assumption of effectiveness, in that only the current standard may come to be effective" ${ }^{\prime \prime}$.

Assuming that the rules relating to fundamental rights have their undeniable force in Brazil, once properly meet enshrined in the body of the Constitution in force, step to examine its effectiveness itself.

Contemporary Brazilian constitutional doctrine, as in Sarlet ${ }^{8}$, Dirley da Cunha Júnior ${ }^{9}$, Virgílio Afonso da Silva ${ }^{10}$ and José Afonso da Silva ${ }^{11}$, distin-

${ }^{5}$ I. W. Sarlet, Dignidade da pessoa humana e direitos fundamentais na Constituição Federal de 1988, Livraria do Advogado Editora, Porto Alegre 2011 [9th ed.], p. 235.

${ }^{6}$ Constituição da República Federativa do Brasil, DF. Senado Federal, Brasília 2011, p. 1

${ }^{7}$ I. W. Sarlet, op.cit., p. 236.

${ }^{8}$ Ibidem.

9 D. da Cunha Júnior, Curso de Direito Constitucional, Editora jusPoDIVM, Salvador 2011 [5th ed.], p. 157.

${ }^{10}$ V. A. da Silva, Direitos Fundamentais: conteúdo essencial, restrições e eficácia, Malheiros Editores LTDA, São Paulo 2011, p. 212.

11 J. A. da Silva, Curso de Direito Constitucional Positivo, Malheiros Editores, São Paulo 2000 [17th ed.], pp. 101-102. 
::̊: R. E. dos Anjos Siqueira, T. J. Wenczenovicz, The constitutional principles... 51

guishes between the full effectiveness standards, such as those enshrining political rights and civil liberties, and the rules of limited effectiveness, those enshrining social rights. This is proved by the way it makes up its effectiveness. The full effectiveness of standards is not necessary for its execution, nothing but the abstention of the state and the ordinary legislator. Once enacted the norm, it immediately produces the desired effects without any state intervention required, except, of course, in cases of violation of these rules when it will need state intervention for its guarantee. In the case of limited effectiveness standards, state intervention is essential to its effectiveness, since, because they are social rights, their realization depends on a state action, without which the effectiveness of the standard does not produce complete. In this sense, the lesson of V. A. da Silva:

"Full effectiveness would have the rules, since the promulgation of the constitution and that already gather all the elements necessary to produce all the desired effects. Of limited effectiveness, in contrast, would be those rules that depend on any further regulation to complete their effectiveness" ${ }^{\prime 12}$.

Once established that effectiveness is the ability to produce legal and factual effects, and that term is presupposed for this same effectiveness and means the legal existence of the standard, has put the importance of determining what the fundamentals of vertical efficiency with regard to realization of fundamental rights in relations between the state and individuals. In the wake of the lessons of the teacher Adriana Zawada Melo, is "the guarantee that contemporary states seek to offer every individual to take your life in accordance with human dignity, fundamental human rights find their explanation and his inspiration"13.

12 V.S. da Silva, op.cit., p. 254.

13 A. Z. Melo, A dignidade da pessoa humana como fundamento da efi cácia horizontal dos direitos fundamentais, [in:] D. Gozzo (ed.), Informação e direitos fundamentais: a efi cácia horizontal das normas constitucionais, Saraiva, São Paulo 2012, p. 16. 


\section{The constitutionalization of the CiVIL LaW}

Once settled the issue of vertical effectiveness of fundamental rights standards and placing the dignity of the human person as the foundation of vertical effectiveness of fundamental rights, it adds up necessary to look at a recent phenomenon of the doctrine of fundamental rights, namely the constitutionalization of the civil law.

The post-World War II international scene, brought a number of innovations in the field of international law, in particular with regard to the issue of international treaties and conventions on the subject of fundamental rights and guarantees. The issue is gaining more relevance in Western legal systems to the point of various constitutions have included in their texts a unique chapter to regulate fundamental rights and guarantees.

Among the various socio-political consequences of this scenario are the various innovations in constitutional law, in particular the theory that there is intense dialogue and irradiation of the norms, values and constitutional principles in Private Law, a phenomenon that has been called the constitutionalization of law.

This constitutionalization of law gives new dimensions to the relationship between the constitutional normative instruments and other infra constitutional legislation, to the point of affirming that the Constitution irradiates values and assumptions in order to change postulates once considered sedimented, such as private autonomy, held dear to scholars of civil law. This radiation then generates several conflicts between the branches of Constitutional Law and Private Law, specifically regarding the effectiveness of fundamental rights.

We see the lesson of Professors Riva Sobrado de Freitas and Alexandre Clemente Shimizu, about the implication of this new understanding of the influence of the Constitutional Law on Civil Law:

"Under this new perspective and parallel to its dissemination, we note overcoming the idea that the fundamental rights only if it would render the protection of citizens in the face of the state, they as essential values of the signed memorandum, come to be understood as "postulates social ", which express a set of values, which provides the source of inspiration, drive and guidance for linking 
:::: R. E. dos Anjos Siqueira, T. J. Wenczenovicz, The constitutional principles... 53

both the legislative process and the acts of public administration and also of all jurisdiction" ${ }^{\prime 14}$.

In this paper, the term constitutionalization of law is used and understood in its broadest sense. It could be said that this expression should be understood as a phenomenon where the legal system of a given country functions under a Constitution endowed with supremacy, though this definition is non-specific and does not address all the senses affects this novel phenomenon.

What we want to demonstrate to the affirmation of a constitutionalization of civil law is the fact that there is a strong reflection of the "expansive effect that the constitutional requirements have acquired over the past 50 years. Such diffusion focuses on the material and axiological content of the constitutional provisions, which reflects intense normative force for the entire legal system" ${ }^{\prime 1}$.

Thus, we can see a large impregnation of the legal system by constitutional standards, expanding the irradiation of the Constitution to all spheres and branches of modern law. This effect is particularly noticeable in the systems of Western countries, gaining strength in the post-war period with the proclamation of the declaration of fundamental rights and the movement for the protection and promotion of human dignity.

An important effect of the constitutionalization of civil law, particularly for the development of this work is the linkage of interpersonal relations to the fundamental rights. This is due to the overcoming of the liberal view, for which the fundamental human rights shall take effect only in relations where the state is a part and the citizen is at the other end. This new vision is relevant, especially in the view presented by Freitas and Clemente, in the lesson described below:

"It is clear, finally overcoming the liberal view, in which the fundamental rights should only take effect in the relationship between state and citizens. This limited design, following the constitutionalization phenomenon, recognized that

14 A. S. Clemente, R. S. de Freitas, A incidência dos Direitos Fundamentais nas relações privadas, [in:] N. L. X Baez et al. (ed.), Dimensões Materiais e Eficáciais dos Direitos Fundamentais, Conceito Editorial, São Paulo 2010, pp. 69-70.

15 Ibidem, p. 71. 
in today's society is not always the state the greatest corrupter of Fundamental Rights, for this post, it is often occupied by individuals, especially those endowed with some social or economic power"16.

Therefore, it is imperative to conclude that the constitutionalization of civil law culminates by bringing new ways of implementation of fundamental rights in interpersonal relations, going beyond the citizen to the state protection, allowing individuals to evoke such rights for their protection in their relations with the State and other citizens.

\section{TheORIES ABOUt THE APPLICABILITY} OF THE FUNDAMENTAL RIGHTS TO PRIVATE RELATIONSHIPS

The acceptance of linking the special relationship to fundamental rights is the first step faced by scholars who, from there, then pass, the task of developing theories and propose models for the application of fundamental rights in interpersonal relations.

Below, follow the three most important theories about the effects of fundamental rights in relations between individuals: Theory of direct application or immediate effect; Theory applicability or indirectly mediate efficacy and; Theory of inapplicability or State Action.

\subsection{THE THEORY OF DIRECT APPLICATION OR IMMEDIATE EFFECT}

This theory is the most accepted among Brazilian scholars, and has been understood, even by the Supreme Court as the most appropriate to our national law. As we noted in the words of Freitas and Clemente:

"It is submitted that this theory, as stated elsewhere, is certainly the one with more supporters in the Brazilian doctrine, it seems appropriate to mention the main theses developed between us, which consider national law (imbued with a social-democratic constitutional paradigm), which imposes, in a way, a unique model that aims to meet the individualized needs of our society"17.

16 Ibidem, p. 75.

17 Ibidem, p. 84. 
:::: R. E. dos Anjos Siqueira, T. J. Wenczenovicz, The constitutional principles... 55

The theory of direct application or immediate effectiveness has its origins in Germany and was initially developed by Hans Carl Nipperdey in the mid-50s, and seeks to argue that no direct linkage of Fundamental Rights in both aspects of social relationships, whether between individuals and the State is in conflicts between individuals.

In direct application of fundamental rights, the particular conflict can evoke such rights without the need to find any "bridges" or "gateway" originated in Private Law, since to this theory Fundamental Rights are considered as subjective rights of individuals in the development of their relations. This means affirming the real possibility for individuals to assert fundamental rights against other individuals.

Freitas and Clemente teach towards the Theory of Direct Applicability require weighting rights when their use in a specific case, as shown below:

"It is worth noting also that the supporters of this theory do not not ignore the existence of specific in its application and, therefore, before a case, recognize the need for balance between the fundamental right and the private autonomy of individuals involved in the relationship"18.

So, applying this theory to the case makes necessary using the weighting or balancing of rights, in other words to say it should be applied to the situation the factual balancing between the conflicting rights. This is to say that the greater the restriction to the right, the greater must be the importance of realization of other rights as opposed to that limited.

When deciding on proceedings, the judge should assign value and importance of satisfaction to discuss rights and judge which one is more relevant to society by providing the most important accomplishment and achievement at the expense of other rights which will have its limited effectiveness. Thus, for this theory, Fundamental Rights can be applied directly in interpersonal relations, using the balancing of rights when there are conflicts between them, just as they are in relations between the state and the individual.

${ }^{18}$ Ibidem, p. 82. 


\subsection{THEORY OF INDIRECT APPLICABILITY OF MEDIATE EFFECTIVENESS}

This theory about the effects of fundamental rights in interpersonal relations is an intermediate construction between theory that denies the binding, also called the State Action, and one that says the direct and immediate effect, treated the topic above.

It has its beginnings in Germany, being its precursor Günter Durig, and is being adopted today, predominantly in that country, especially by the German Constitutional Court.

Its scope of the search for balance between private autonomy on the one hand, and fundamental rights on the other. This is due to this theory recognize a general right of freedom, in response to an attempt to avoid domination of private law by the constitutional law.

Thus, this thesis draw up an effective model of fundamental rights in private relations which allows the binding occurs through the intermediation of norms and principles peculiar to private law in the form of general provisions and indeterminate concepts. That is, so there is linkage of fundamental rights in private relationships, the theory Effectiveness mediately, demand the existence of "bridges" between the public law and private in the form of general clauses or indeterminate concepts.

In the words of Freitas and Clemente:

"In this vein, the Fundamental Rights represent an objective order of values, or even a system of values, causing their radiating effects are felt in all branches of law. In private law, these values (ie, Fundamental Rights) step into the private sphere through the general clauses and indeterminate concepts" ${ }^{\prime 19}$.

\subsection{The theory of inapplicability or the theory of State Action}

Being predominantly accepted in the United States, this thesis has its basis in liberal view. This theory denies primarily linking the special relationship to fundamental rights. However, a closer study of the concepts and application of this theory reveals a contradiction between the theoretical and the

${ }^{19}$ Ibidem, p. 79. 
::̊ R. E. dos Anjos Siqueira, T. J. Wenczenovicz, The constitutional principles... 57

practical. It is an apparent denial of the link, but that case law, is revealed as effectiveness of Fundamental Rights in interpersonal relations, as will be shown below.

Because of its apparent denial of the binding, the Theory of State Action found a loophole to apply the fundamental rights in relations between individuals. This device is to give the state responsibility for acts of private order, or even make the assimilation of these through acts of public policy. Through this legal fiction, the scholars of the Theory of State Action can solve, albeit unsystematic way, equating the dilemma of knowing when a private action has possibility to compare or even be transformed into public action.

According to the lesson Freitas and Clement, we see that:

"Despite the Theory of State Action wants to deny (although apparently) the binding of Fundamental Rights, the judicial work of the Supreme US Court ends up finding, one way or another, a conformation that private action, transforming it in public, ensuring thereby that preserves a rifled constitutional right" ${ }^{\prime 20}$.

Thus, we see that even if there is apparent linking negative for those who deny such a possibility, the courts find ways to remedy the violation of fundamental rights in private relationships, forcing the conclusion that such rights are of utmost importance to the full realization of democracy and the protection of the democratic rule of law.

\section{THE PRINCIPLE OF HUMAN DIGNITY}

based on the achievement of fundamental rights in the relations between state and individual as well as in relations between individuals, remains conceptualize human dignity, in order to situate it between the grounds of the effectiveness of those rights.

Through the study of fundamental rights and, in particular, of the historical process of conquest and acquisition of those rights, we stumbled on the concept of equality under the law. However, this legal equality must be understood in a different light than the simple definition of the word, there-

${ }^{20}$ Ibidem, p. 77. 
fore, manifests itself in a very peculiar way, intrinsically linked to the notion of dignity.

By stating that all are equal before the law, you must have in mind that not all people are in fact equal in many ways. So, for the right to equality, the right to differences arises. Therefore, in this strict sense, the concept of equality must allow the recognition of differences, such as those related to gender, race, age, etc. Only then can we speak of an effective equality and promoting a radical protection and guarantee of rights. Thus, equality, considered in the light of human dignity, guarantees every human being the order of nature itself and grant you the rights to subject status. Then, if it enters under the law of minorities.

In this sense, the right of minorities lends itself to protect portions or vulnerable groups in society, reducing inequalities among citizens. For this perspective, the right of minorities focuses its activities on the human person, as a subject of law, considered in its peculiarities and vulnerabilities and use of formal equality concepts, abstract and general and material equality, concrete and specific, therefore, considers the right to equality and the right to difference, showing the two-dimensional character of justice as redistribution and recognition of identities.

Consolidates, so the two-dimensional character of justice, making necessary an equality that acknowledges differences and a difference that does not produce, or reproduce inequalities. According to Nancy Fraser:

"The recognition of identities is not limited only to the distribution because the status is not due simply in terms of social classes. At the same time, the distribution cannot be reduced to the recognition of identities because access to resources does not result simply in status function"21.

Indeed, the guarantee of rights is not the result of simple assignment of rights subject status, state intervention is necessary, as guarantor entity, in the implementation of established standards and is, ultimately, to give the citizen their dignity.

${ }^{21}$ N. Fraser, Redistribución, reconocimiento y participación: hacia un concepto integrado de la justicia, UNESCO, Paris 2000-2001, pp. 55-56. 


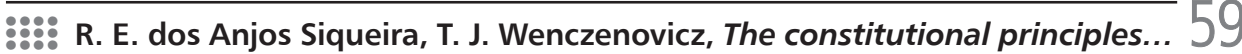

Doctrinally conceptualize dignity is not an easy task. Being relatively recent development, because only after the Second World War, went beyond the sphere of philosophy and today is imbricated in the legal systems and political discourse without any possibility of return. It is also difficult to specify the concept of human dignity under cover itself other concepts such as "human person" and "dignity". This idea of human dignity is inextricably linked to the concepts of freedom and equality, both older development than that.

For several years the concept of human dignity was closer to philosophy, and therefore owned status value and not standard. For this reason, it is that one can understand the absence of the legal systems that emerged from the French Revolution, as these orders gave greater importance to formal equality and positivism has always prioritized the norm at the expense of other paradigms. After the Second World War, with all the barbarism that characterized, and in the twentieth century is that the dignity of the human person shall be recognized and enshrined as a fundamental principle, as taught by Melo ${ }^{22}$.

For the purpose it is intended for this work, I chose to simplify the discussion of the concept of the human person. I chose to adopt this notion in its broadest possible sense, which is covering all people without distinction of their legal status or citizenship ${ }^{23}$. Even because the very use of the term "human being", rather than the customary "citizen", accustomed word to the liberal conception of constitution, already shows us the legislator's intention to expand the scale of its application as opposed to the concept of limitation citizenship ${ }^{24}$.

Human dignity, therefore, should be understood as the fundamental principle of fundamental rights, although not exhausted these rights their legal content.

The historic building of the modern concept of human dignity goes through several times. One can, with some certainty, say that Christianity is the precursor of the dignity of idea inherent to all men, as among its postulates there is a strong determination that all men were created in the im-

${ }^{22}$ A. Z. Melo, op.cit., p. 16.

23 Ibidem, p. 17.

${ }^{24}$ D. da Cunha Júnior, op.cit., p. 543. 
age and likeness of God himself and therefore are deserving the same treatment must love each other.

It should also be credited to the enlightenment the historical construction of the doctrinal concept of human dignity. Among many others, and as taught by Norberto Bobbio ${ }^{25}$, Immanuel Kant, whose work is still cited in discussions on the subject, is brave exponent of this concept, especially when he said that man must be an end in itself. In the wake of Kant's teachings, we have Sarlet, stating that:

"Yet this perspective, it has been pointed out - rightly, in our experience - to the fact that the performance of social functions in general is linked to a mutual subjection, in such a way that the dignity of the human person, understood as seal human exploitation in principle prohibits the complete and egoistic available on the other, in the sense that if you are using another person only as a means to achieve a particular purpose, in such a way that decisive criterion for identifying a violation of dignity becomes (in many situations, it is proper to add) the objective of the conduct, I mean, the intention to instrumentalize (objectify) the person"26.

Thus, in seeking to conceptualize dignity, we came across some ideas that are akin, and, among them, the impossibility of instrumentalization of human beings ${ }^{27}$. As explained above, the exploitation of one person by another, violates the dignity of the exploited and makes us consider that the dignity of notion is closely linked to the notions of equality and freedom.

Take as an example the fact that someone who subjugated the other, become linked to the interests of this and be used as a means for achieving purposes other than their own, you will find yourself deprived of their freedom and cannot be considered on equal footing with respect to the one that overwhelmed him. There will be, in this case, a flagrant violation of the principle of human dignity, since without the right to self-determination and deprived of their right to formal equality and material, one man leaves his condition of human being, and will identify themselves with the instrument concept, object used to obtain particular purpose.

25 N. Bobbio, A era dos direitos, trans. C. N. Coutinho, Elsevier, Rio de Janeiro 2004 [10th ed.], p. 48.

${ }^{26}$ I. W. Sarlet, op.cit., p. 63.

27 N. Bobbio, op.cit., p. 49. 
::̊ R. E. dos Anjos Siqueira, T. J. Wenczenovicz, The constitutional principles... 61

It is necessary to consider the possibility of subjection of one person by another is due to the will of those who are subject, but, even so, should this unequal situation be understood as an exception to the characterization of the violation of human dignity. In this case, the very willingness to subject itself can be the result of an uneven material or financial, even the result of a weak and conformist mental condition that states that such a circumstance is socially acceptable. This condition can even be invoked by the operator as excluding the possibility of guilt, in the event of a possible criminal responsibility for the act.

However, the dignity of the human person, being inherent in the human condition, cannot be dismissed or waived, precisely because its characteristic of being intrinsic to the human person, and due to the mere condition of being a person. In this view, once again, we turn to the teachings of the teacher Sarlet to state that:

"dignity as an intrinsic quality of the human person, an indispensable and inalienable constituting element that qualifies the human being as such, and it cannot be highlighted in such a way that it cannot entertain the possibility of a particular person hold a claim to be granted dignity"28.

Therefore, dignity cannot be granted to anyone by state administrative act, and not through legislative or judicial process. Clearly the dignity exists not only where it is recognized by the legal system, but its existence is due solely to the existence of person, human being. In the presence of the human being there is the dignity of the human person. So, being the law of a democratic state the guarantor of rights for excellence, should the government protects it whenever there are violations of dignity or imminent danger of such.

6. THE PRINCIPLES OF FREEDOM AND EQUALITY AS FUNDAMENTS OF THE EFFICACY OF THE FUNDAMENTAL RIGHTS

In a brief study of the Constitution of the Federative Republic of Brazil, we found several devices that point to the correlation between human digni-

${ }^{28}$ I. W. Sarlet, op.cit., p. 52. 
ty, equality and freedom. Art. 1, section III of the Constitution establishes as one of the foundations of our Federal Republic, the dignity of the human person, which can also be considered as the foundation of freedom, equality and other fundamental rights.

This is observed in the following constitutional provisions: Art. 5, caput and item I, where you see this equality; Art, 3, III, where the Constitution is committed to the reduction of inequalities, and the abhorrence of discrimination, in that Art. 3, IV; beyond the literal linking of the Brazilian state with the search for social welfare and social justice, as seen in Art. 170 and 193.

In order to clarify the relationship between human dignity, equality, freedom and the horizontal effect of fundamental rights, I turn to examine, albeit briefly these correlations. For the purposes of this study, this brief analysis is restricted to the study of these concepts and their correlations within the law.

Being an old construction, the freedom and equality concepts are objects of study since antiquity, reassembled to ancient Greece their first doctrinal records, culminating in winning attention at the time the statements of eighteenth century rights and constitutionalism in the early days. On the other hand, the concept of human dignity, is the beginning of his doctrinaire treatment from the Middle Ages, climbing precedence under constitutional law in the contemporary era ${ }^{29}$.

Arduous task is to conceptualize equality, as to be open to a large number of evaluative criteria, it has been and is subject to the content variations throughout history since, as the ideological movements alternate their conceptualization to the world of law, also undergoes changes often significant.

Under the specific perspective of the law, it can be stated with reasonable safety and Melo teaches ${ }^{30}$, the intimate connection between equality and justice, not only with regard to social justice, but also in the context of commutative and distributive justice. In essence, this close relationship is often the fruit that is questioned activity to do justice when it is understood as the set of action which is due to each. This is what teaches Melo, citing Lopes:

${ }^{29}$ A. Z. Melo, op.cit., p. 23.

${ }^{30}$ Ibidem. 
:ஃ: R. E. dos Anjos Siqueira, T. J. Wenczenovicz, The constitutional principles... 63

"The theory of justice always begins with the issue of equality. So much so that the pursuit of formal rule of justice often ends in the formulation of the following proposition: «Justice is an action principle that the beings of the same class must be treated the same way»"31.

According to this understanding, all citizens must obtain from the state, the same treatment is in the administrative, legislative or judicial. The state has a duty to provide everyone with the same measure of care and protection. This obligation arises from the law itself. The rule, which states that all are equal before the law, saying the State that it must provide to all beings within its jurisdiction one equal treatment in law enforcement. As is clear from the lesson of Robert Alexy:

"In detail, the duty of equality in law enforcement has a complicated structure, for example where it requires the development of related rules to the case, either for the accurate determination of vague concepts, open ambiguous and evaluatively, either for the exercise of discretion. At its core, however, this duty is simple. It requires that all legal standard to be applied to all cases which are covered by their factual support, and any case that is not, which means nothing more to say that legal rules must be met. (emphasis added)" ${ }^{\prime 2}$.

Professor Cunha Júnior, elucidates the issue of equality before the law as follows:

"The right to equality is the right of everyone to be treated equally in that are equal and unequally the extent that desigualem either to the law (formal equality), either to the opportunity of access to the goods of life (material equality), because all people are born free and equal in dignity and rights. The demand for equality stems from the constitutional principle of equality, which is a basic tenet of democracy because it means that everyone deserves the same opportunities, closed with any kind of privilege and persecution. The first screen prohibited unequal treatment to the same people and the same as the unequal people"33.

31 Ibidem, p. 23.

32 R. Alexy, Teoria dos Direitos Fundamentais, trans. V. A. da Silva, Malheiros Editores LTDA, São Paulo 2011 [2nd ed.], p. 394.

${ }^{33}$ D. da Cunha Júnior, op.cit., p. 676. 
As teaches Cunha Júnior, equality manifests itself in two forms: the formal equality and equality material. Formal equality, for teaching purposes, can be subdivided into equality in law and equality before the law, understood as the development of standards that do not contain distinction that is not authorized by the Constitution, preventing the legislature from creating rules that may break the isonomic order; and that the application of the law equally to all, even if you create inequality, preventing law enforcement is made according to discriminatory criteria or privilege. Have material equality must be understood as the application of the law to the case, taking into account the subjects of rights in their peculiarities and subjectivities, in order to provide an administrative action or judicial assistance with equity in the specific case ${ }^{34}$.

In other words, in consideration of the concept of equality in the development and application of the law, it must be taken into account that there are two types of discrimination: those opposing and those favoring the set of values, principles and rights enshrined in the Constitution parents. Being sealed the opposed and should be promoted by the latter to be effective measures delivery of justice with equity, and mainly because they are enshrined in the Constitution itself, as necessary standards and mechanisms.

This is a masterful lesson from Flávia Piovesan when she states that are essential for the implementation of the right to equality, combating discrimination and promoting equality:

\footnotetext{
"In contemporary perspective, the realization of the right to equality implies the implementation of these two strategies, which cannot be separated, that is, today combating discrimination becomes insufficient if there are no measures aimed at promoting equality. In turn, the promotion of equality by itself, it is insufficient if there are no anti-discrimination policies"35.
}

So we have that equality is the fundamental principle in the realization of fundamental human rights, and is inextricably linked to the dignity of the human person when understood as assumption of realization of justice.

\footnotetext{
34 Ibidem, pp. 543-544.

35 F. Piovesan, Temas de Direitos Humanos, Saraiva, São Paulo 2010, p. 243.
} 
:::: R. E. dos Anjos Siqueira, T. J. Wenczenovicz, The constitutional principles... 65

In turn, the concept of freedom, is the beginning of his theoretical construction dating back to ancient Greece, and also presents multifaceted and affected by various ideological fluctuations in historical times. Aiming to achieve the purposes for which it is proposed this test is restricted, the brief analysis that will make the concept of freedom, the scope of the law.

It is from the nineteenth century that the legal meaning of freedom begins to dissociate and establish its independence from the philosophical meaning of that freedom. This is due to the fact that it is at that time that began to be enshrined civil liberties and fundamental rights. Today, freedom is enshrined as a fundamental human right, and the example of equality, in the words of Melo, it can be considered "as a value, as a principle and as a rule. In terms of meaning, freedom is increasingly rich, and you can better understand it from a global vision of two great 'rating blocks' positive freedom and negative freedom"36.

Continues Melo to teach:

"The first covers everything that relates to the classic autonomy of the will, and the second concerns the possibility of the individual to act without interference or obstacles, whether opposed by the State or by individuals. In addition to this classification, one can still distinguish between real freedom, represented by the absence of obstacles to personal someone to do something, and formal freedom, which translates in legal freedom, ie in the absence of legal obstacles to individual action. In the area of legal freedom should be mentioned political freedom, which simultaneously identifies with the possibility of democratic participation" ${ }^{\prime 37}$.

Thus, we must understand that freedom in its various forms of expression, it follows that the citizens should have guaranteed their right to free determination of his will, to no impediment to act in accordance with the law, active participation in the political decisions of their parents. However, all forms of freedom of expression also bring in its wake the limitation of that freedom when exercised in society.

This is due to the fact that for that exercise their right to freedom for all citizens, it is necessary to impose limits on this same right, in an attempt to

${ }^{36}$ A. Z. Melo, op.cit., p. 28.

37 Ibidem. 
ensure equal social life. Paradoxically, for all to enjoy, simultaneously, the freedoms won, mister there are restrictions on the exercise of individual freedom in order to guarantee human dignity. To these restrictions, we call responsibility.

Thus, freedom can be legally understood as the ability of human beings to determine their will freely, even to refrain from acting, jealous of their liability for each act or omission her before their fellow citizens and to society generally, represented by the state coercive apparatus.

Finally, as appears from the above, freedom and equality are founded on human dignity. And when enshrined this right, the legislature aims to prevent the abuse of power, whether by an individual, group of individuals or the state itself.

Being denied the link between these values, norms, principles, remains conclude that if dignity is indeed the ultimate foundation of these values as it is for the fundamental rights and should serve to support its practical and doctrinal aspects, always bringing their interactions with the concepts of equality and freedom.

\section{THE HORIZONTAL EFFICACY OF THE FUNDAMENTAL RIGHTS}

It is in the pursuit of social equality and the evaluative increase accumulated for human rights in the early twentieth century that gave birth to differentiate between vertical effectiveness (already addressed before) of the horizontal effect of fundamental rights (to be treated in this topic).

Established that there are differences between the vertical and the horizontal effectiveness of fundamental rights is not simply divide between public and private freedoms and name those as vertical as horizontal effectiveness and these effectively.

Understanding proposed here is to highlight the difference between the two efficiency levels, vertical and horizontal, of fundamental rights, since they are binding on all, in different ways, according to the ball and relationships on which encompass both in the public or private aspect.

Likewise, the teachings of Melo and Costa Júnior: "When it comes in vertical and horizontal efficacies, is intended to allude to the distinction be- 
:̊: R. E. dos Anjos Siqueira, T. J. Wenczenovicz, The constitutional principles... 67

tween the effectiveness of the fundamental rights of the Government and the effectiveness of fundamental rights in relations between individuals"38. Still based on the teachings of Melo, one can adduce:

"In his classic feature, the theory of horizontal effect of fundamental rights advocates that those rights are not enforceable only against the state and its agents, which would sense when its historical appearance, but also within the private relations, directly (effectiveness or immediate relevance) or through state act intermedeie this application (mediate efficacy or relevance)"39.

Thus, the effectiveness of fundamental rights is an institute that all links and under its aegis all, Brazilians and foreigners during their stay in the country, should guide their conduct, without infringing the principle and constitutional rule. So even in relations between individuals, they should be considered with priority, fundamental rights.

Given that fundamental rights have as its theoretical basis and main ground the dignity of the human person must, likewise, be understanding that these rights are also applied in relations between individuals. However, there is some resistance from the private law doctrine to accept any limitations, even if derived from the Constitution, the freedom of choice or, ultimately, freedom and equality.

In response to the resistance of the scholars of private law the opposition limits the freedom of choice as a result of the horizontal effect of fundamental rights, I invoke the lesson pf Melo:

"One can easily sustain the horizontal effect of fundamental rights as a mere consequence of the constitutional treatment of various institutes of private law and/or as a result of the principle of constitutional supremacy, in the sense that the constitutional requirements are norms of higher hierarchy, which must always prevail and that permanently radiate a parametric and shaping effect to any legal, public and private land"

38 A. de O. Costa Junior, A. Z. Melo, Eficácia vertical e horizontal dos direitos fundamentais, „Revista Mestrado em Direito” 7 (2007), No. 1, p. 262.

39 A. Z. Melo, op.cit., pp. 31-32.

40 Ibidem, p. 32. 
Undeniable, as it turns out, the effectiveness of fundamental rights, either in verticality or horizontality of human relations, either by nature of constitutional rule and the consequent primacy in national law, either by its main foundation in the dignity of the human person. It is held later this horizontal effect of fundamental rights by virtue of its main foundation in the dignity of the human person, in its correlation with the concepts of equality and freedom.

Taking as a definition of dignity, Aline Albuquerque S. de Oliveira teaches:

"It is the value that is revealed in every person just because exist, which means that the dignity is immeasurable and static. Human people do not lose or gain dignity, as there is no way to measure it or upgrade it. The inherent dignity intrinsic to being, is not assigned, but a given limiting human activity and concomitantly liberating"41.

Finally, it remains to admit the need for recognition of human dignity as a basic and defining element of the human condition and cannot therefore be dissociated from human existence, denied, granted, waived, destitute or relegated to the status of secondary attribute.

For all the foregoing, there is a fact that the dignity of the human person is the last and main foundation of the effectiveness of fundamental rights in the public sphere (relations between state and private) and the private sphere (relations between individuals).

\section{ConcLusions}

Considered the concepts of equality, liberty and human dignity in its historic construction, one sees a clear link between them. It should be noted that the first two, although oldest legal-philosophical constructions that the latter, are mainly a plea and therefore are seen as subsidiary to the dignity of the human person in his capacity of human rights fundaments.

Throughout history, the dignity of the human person has to take precedence as the foundation of fundamental rights, especially because of their

${ }^{41}$ A. A. S. de Oliveira, Bioética e Direitos Humanos, Edições Loyola, São Paulo 2011, p. 90 . 
:ஃ: R. E. dos Anjos Siqueira, T. J. Wenczenovicz, The constitutional principles... 69

positive on normative instruments, constitutions and bills of rights, making it, in contemporary law, the fundamental principle of the fundamental human rights.

The insertion of human dignity in the constitutional texts can also be identified as a decisive factor for its ground condition in the effectiveness of fundamental rights in the vertical level, that is, in relations between the state and individuals.

The search for the expansion of the scope of this effectiveness by linking of individuals is what gave rise to the theory of horizontal effect of fundamental rights, just as the vertical efficiency, has its main foundation in the dignity of the human person.

Thus, it is recognized the foundational character of the human dignity to the horizontal effect of the fundamental rights. This is a result of the supremacy of constitutional norms, the intertwining of the dignity, equality and freedom and decision to prioritize certain basic values of national law.

A BSTRACT

This paper aims to examine the constitutional principles of freedom and equality as fundaments of the efficacy of the human dignity. As a method, it uses the literature and Brazilian contemporary constitutional doctrine review. It also aims to study their correlations and relevance for the fundamental rights study. For that purpose, it shows the historical construction of the concept of human dignity, finding the points of intersection between human dignity, freedom and equality, and in a synthetic way to reach the contemporary conception of dignity as the foundation of human rights. The problem here is treated from the perspective of contemporary law, especially in its constitutional meaning, demonstrating that the constitutional principles of freedom and equality are the foundations for human dignity and for the effectiveness of fundamental rights in relations between the state and individuals, as it should also be in the relations between individuals or a horizontal effect. 